\title{
Peripheral Myelin Protein 22 Is in Complex with $\alpha 6 \beta 4$ Integrin, and Its Absence Alters the Schwann Cell Basal Lamina
}

\author{
Stephanie A. Amici, ${ }^{1}$ William A. Dunn Jr, ${ }^{2}$ Andrew J. Murphy, ${ }^{3}$ Niels C. Adams, ${ }^{3}$ Nicholas W. Gale, ${ }^{3}$ \\ David M. Valenzuela, ${ }^{3}$ George D. Yancopoulos, ${ }^{3}$ and Lucia Notterpek ${ }^{1,2}$ \\ Departments of ${ }^{1}$ Neuroscience and ${ }^{2}$ Anatomy and Cell Biology, College of Medicine, McKnight Brain Institute, University of Florida, Gainesville, Florida \\ 32610-0244, and ${ }^{3}$ Regeneron Pharmaceuticals, Inc., Tarrytown, New York 10591
}

\begin{abstract}
Peripheral myelin protein 22 (PMP22) is a tetraspan membrane glycoprotein, the misexpression of which is associated with hereditary demyelinating neuropathies. Myelinating Schwann cells (SCs) produce the highest levels of PMP22, yet the function of the protein in peripheral nerve biology is unresolved. To investigate the potential roles of PMP22, we engineered a novel knock-out $(-I-)$ mouse line by replacing the first two coding exons of $p m p 22$ with the lacZ reporter. PMP22-deficient mice show strong $\beta$-galactosidase reactivity in peripheral nerves, cartilage, intestines, and lungs, whereas phenotypically they display the characteristics of tomaculous neuropathy. In the absence of PMP22, myelination of peripheral nerves is delayed, and numerous axon-SC profiles show loose basal lamina, suggesting altered interactions of the glial cells with the extracellular matrix. The levels of $\beta 4$ integrin, a molecule involved in the linkage between SCs and the basal lamina, are severely reduced in nerves of PMP22-deficient mice. During early stages of myelination, PMP22 and $\beta 4$ integrin are coexpressed at the cell surface and can be coimmunoprecipitated together with laminin and $\alpha 6$ integrin. In agreement, in clone $\mathrm{A}$ colonic carcinoma cells, epitope-tagged PMP22 forms a complex with $\beta 4$ integrin. Together, these data indicate that PMP22 is a binding partner in the integrin/laminin complex and is involved in mediating the interaction of SCs with the extracellular environment.
\end{abstract}

Key words: basal lamina; integrins; Schwann cells; myelination; neuropathy; laminin

\section{Introduction}

Myelination in the peripheral nervous system (PNS) is dependent on the secretion of a basal lamina by Schwann cells (SCs) (Bunge, 1993). This linkage with the extracellular matrix (ECM) stabilizes axon-SC contacts and permits the initiation of myelination (Eldridge et al., 1987, 1989). Integrins, specifically $\alpha 6 \beta 1$ and $\alpha 6 \beta 4$, play key roles in mediating the interaction between SCs and basal lamina constituents, such as laminin (Previtali et al., 2001). Besides integrins, SCs express a number of adhesive proteins, including myelin-associated glycoprotein, myelin protein zero, and peripheral myelin protein 22 (PMP22), which play critical roles at various stages of myelination (Schachner and Martini, 1995). These molecules contain the L2/HNK-1 adhesion/recognition carbohydrate epitope that can modulate cellcell and cell-matrix interactions.

PMP22, a putative tetraspan glycoprotein, is thought to be a

Received June 24, 2005; revised Dec. 5, 2005; accepted Dec. 5, 2005

This work was supported in part by the National Institutes of Health-National Institute of Neurological Disorders and Stroke, the Muscular Dystrophy Association, and the State of Florida Brain and Spinal Cord Injury Rehabilitation Trust Fund. We thank the University of Florida College of Medicine Electron Microscopy Core Facility and Debbie Akin for technical assistance with the morphological studies and Dr. Arthur Mercurio for the gift of the clone A cells. We also thank Drs. Eric M. Shooter and Kyle J. Roux and members of the Notterpek laboratory for helpful discussions.

Correspondence should be addressed to Dr. Lucia Notterpek, Department of Neuroscience, McKnight Brain Institute of the University of Florida, 100 Newell Drive, Box 100244, Gainesville, FL 32610-0244. E-mail: notterp@mbi.ufl.edu.

DOI:10.1523/JNEUROSCI.2618-05.2006

Copyright $\odot 2006$ Society for Neuroscience $\quad$ 0270-6474/06/261179-11\$15.00/0 key molecule in PNS myelin, because its misexpression is associated with hereditary demyelinating neuropathies (Naef and Suter, 1998). Although the exact function of PMP22 in the SC membrane is still unclear, the phenotypes of mice deficient in PMP22, or expressing mutated copies, suggest an involvement in myelin formation and maintenance (Adlkofer et al., 1995; Maycox et al., 1997; Robertson et al., 1997). One mechanism by which PMP22 may influence myelin stability is by interacting with the extracellular domain of protein zero (D'Urso et al., 1999; Hasse et al., 2004). An additional role in embryonic and early postnatal development is supported by the expression of PMP22 by migratory neural crest cells (Hagedorn et al., 1999) and the dysmyelinating phenotypes of PMP22 mutant rodents (Martini and Schachner, 1997; Notterpek and Tolwani, 1999). In agreement, certain mutations in PMP22 are associated with childhood-onset dysmyelinating neuropathies in humans (Roa et al., 1993; Garcia et al., 1998).

The localization of PMP22 at cell-cell junctions of various epithelia and endothelia suggests a possible role in mediating myelin wrapping and intercellular adhesion (Notterpek et al., 2001; Roux et al., 2004, 2005). Overexpression of PMP22 in epithelial cells alters their migratory behavior and changes the functional properties of cell-cell contacts (Roux et al., 2005). In addition, in NIH3T3 cells (Brancolini et al., 1999) and rat SCs (Nobbio et al., 2004), the overexpression of PMP22 mediates membrane expansion. These findings, together with the pheno- 
types of PMP22 mutant mice, indicate that PMP22 is capable of modulating intercellular and cell-matrix communications in a variety of cell types. How PMP22 attains these functions in the plasma membrane is still unknown but could involve direct or indirect links with constituents or binding partners of the ECM.

To elucidate the potential roles of PMP22 in the cell membrane, we engineered a novel PMP22-deficient mouse line. Affected mice broadly express the LacZ reporter in a variety of neural and non-neural tissues and display tomaculous neuropathy. Ultrastructural analyses of sciatic nerves revealed alterations in the SC basal lamina, which led us to examine the potential interaction of PMP22 with integrins. By a variety of approaches, we show that PMP22 is a binding partner for the $\alpha 6 \beta 4$ integrin complex.

\section{Materials and Methods}

PMP22-deficient LacZ mice. This PMP22-deficient LacZ mouse line was engineered using the VelociGene targeting technology (Valenzuela et al., 2003). A breeding colony was maintained under specific pathogen-free housing. The Institutional Animal Care and Use Committee approved the use of animals for these studies. For genotyping, DNA was isolated from tail biopsies of pups under $<10 \mathrm{~d}$ old and digested with BamHI. Genotypes were determined by Southern blot analysis using a $1.4 \mathrm{~kb}$ probe, which recognizes a portion of the murine pmp22 upstream of the start codon ( $5^{\prime}$ probe) and a portion of the neomycin resistance gene (neo probe). The lacZ reporter activity was detected histochemically on embryonic day 15 (E15) and adult heterozygous tissue samples by X-gal staining (Valenzuela et al., 2003). Sections from the embryos were counterstained with neutral red. Whole-mount preparations were imaged using a Leica (Nussloch, Germany) MZ12.5 dissecting microscope with a ColorView II camera (Soft Imaging Systems, Lakewood, CO). Cryostat sections were scanned using an Aperio ScanScope, and all images were formatted for printing with Photoshop CS (Adobe Systems, San Jose, CA).

Morphological analyses and teased nerve fiber preparation. All reagents used for these studies were obtained from Electron Microscopy Sciences (Fort Washington, PA). Sciatic nerves were collected from genotyped postnatal day 3 (P3), P10, P13, and P18 mice. Samples were fixed by immersion in $1 \%$ glutaraldehyde $/ 2 \%$ paraformaldehyde in $0.1 \mathrm{~m}$ sodium cacodylate buffer, $\mathrm{pH} 7.4$, overnight at $4^{\circ} \mathrm{C}$, followed by osmication in $2 \% \mathrm{OsO}_{4}$ in $0.1 \mathrm{M}$ sodium cacodylate buffer for $1 \mathrm{~h}$ at room temperature, dehydrated in an ascending ethanol and acetone series, and embedded in Spurr's medium. Thick sections of the samples were stained with toluidine blue and surveyed by light microscopy using a SPOT camera (Diagnostic Instruments, Sterling Heights, MI) attached to a Nikon (Melville, NY) Eclipse E800 microscope. Measurements of axon and fiber (axon with myelin) diameters on light level images were obtained using Advanced SPOT RT software (Diagnostic Instruments). G-ratios were determined by dividing the axon diameter by the fiber diameter. To quantify potential differences in G-ratios, $>100$ individual fibers per animal were analyzed, using four to five mice per genotype. Statistical analysis was performed using Excel 2000 software (Microsoft, Redmond, CA). Thin sections of the samples were poststained with lead citrate and uranyl acetate and examined on a Jeol (Peabody, MA) 100CX transmission electron microscope. Images were formatted for printing by using Photoshop 5.5.

Details of the teased nerve fiber procedure were described by Martini et al. (1995). Briefly, sciatic nerves from genotyped P21 mice were collected and preteased into small bundles, followed by osmification and dehydration, as above. Single fibers were obtained by teasing the nerves in embedding medium, and slides were baked overnight at $60^{\circ} \mathrm{C}$. Light microscopy was performed using a Nikon T1-SM inverted microscope equipped with a Nikon DS-L1 camera.

Myelinating dorsal root ganglion neuron-SC cocultures. Rat dorsal root ganglion (DRG)-SC cocultures were established as described previously (Notterpek et al., 1999). DRGs were collected from E15 rodents, digested with $0.25 \%$ trypsin (Invitrogen, Rockville, MD), dissociated, and plated on rat tail collagen (Biomedical Technologies, Stoughton, MA)-coated glass coverslips. Explants were maintained in minimum essential medium (Invitrogen) supplemented with 10\% fetal calf serum (Hyclone, Logan, UT), $0.3 \%$ glucose (Sigma-Aldrich, St. Louis, MO), $10 \mathrm{~mm}$ HEPES (Cellgro; Mediatech, Herndon, VA), and $100 \mathrm{ng} / \mathrm{ml}$ nerve growth factor (Harlan Bioproducts for Science, Madison, WI) for $7 \mathrm{~d}$. Ascorbic acid ( $50 \mu \mathrm{g} / \mathrm{ml}$; Sigma-Aldrich) was then added for an additional $15 \mathrm{~d}$, at which point the cultures were used for biochemical studies.

Immunolabeling of nerves. Sciatic nerves were dissected from genotyped P10 and 3-month-old $+/+$ and PMP22-/ - littermates. Samples were frozen by immersion in liquid nitrogen-cooled $N$-methyl butane. Frozen sections ( $5 \mu \mathrm{m}$ thickness) were dried for $1 \mathrm{~h}$ on Superfrost/Plus microslides (Fisher Scientific, Pittsburgh, PA), followed by fixation with $4 \%$ paraformaldehyde in PBS for 10 min at room temperature and permeabilization with $100 \%$ acetone for $2 \mathrm{~min}$ at $-20^{\circ} \mathrm{C}$ (MelendezVasquez et al., 2004). Samples were blocked in PBS containing 20\% normal goat serum for $1 \mathrm{~h}$. Primary antibodies, including polyclonal rabbit anti-laminin (1:10,000; Sigma-Aldrich); anti-PMP22 (Notterpek et al., 1999); and monoclonal rat anti- $\beta 4$ integrin (1:4000), anti- $\beta 1$ integrin (1:4000), and anti- $\alpha 6$ integrin (1:4000) (all from BD Biosciences PharMingen, San Diego, CA), were added in the blocking solution overnight at $4^{\circ} \mathrm{C}$. For the PMP22 and integrin double-labeling studies, nerve sections were fixed in $4 \%$ paraformaldehyde $(10 \mathrm{~min}$, room temperature) and permeabilized with $100 \%$ methanol $\left(10 \mathrm{~min},-20^{\circ} \mathrm{C}\right)$ (Einheber et al., 1993). These fixation conditions are optimal for the detection of $\beta 4$ integrin; however, the PMP22-like staining is weaker than usual (Notterpek et al., 1999). The samples were then incubated with Alexa Fluor 594 goat anti-rabbit IgG (red) and/or Alexa Fluor 488 goat anti-rat IgG (green) (both from Molecular Probes, Eugene, OR) for 1-2 h. Hoechst dye \#33342 (Molecular Probes) was included in the secondary antibody solution at $10 \mu \mathrm{g} / \mathrm{ml}$ to visualize nuclei. Coverslips were mounted by using the ProLong Antifade kit (Molecular Probes). Samples were imaged with a Spot camera attached to a Nikon Eclipse E800 microscope or an Olympus Optical (Tokyo, Japan) MRC-1024 confocal microscope and were formatted for printing by using Photoshop 5.5.

Western blot analyses. Sciatic nerves collected from genotyped mice were frozen immediately in liquid nitrogen. For total protein analyses, nerves from three to four mice were crushed under liquid nitrogen and solubilized in SDS gel sample buffer (62.5 mm Tris, pH 6.8, 10\% glycerol, and $3 \%$ SDS). Protein concentrations were determined using BCA reagents (Pierce, Rockford, IL). Samples (20 $\mu \mathrm{g} / \mathrm{lane}$ ) were separated on 7.5 or $12.5 \%$ acrylamide gels under reducing conditions and transferred to nitrocellulose membranes (Bio-Rad, Hercules, CA). Polyclonal antiPMP22 (1:2000); anti- $\beta$-galactosidase ( $\beta$-gal; $1: 1000$; Molecular Probes); anti-laminin (1:10,000; Sigma-Aldrich); anti- $\beta 4$ integrin $(1: 1000)$ and monoclonal rat anti- $\beta 1$ integrin (1:1000; both from Chemicon, Temecula, CA); and monoclonal mouse anti-glyceraldehyde-3phosphate dehydrogenase (GAPDH) (a kind gift from Dr. G. Shaw, University of Florida, Gainesville, FL) were used. Bound antibodies were visualized using an enhanced chemiluminescence kit (PerkinElmer Life Sciences, Boston, MA). Films were digitally imaged using a GS-710 densitometer (BioRad) and were formatted for printing by using Photoshop 5.5.

Coimmunoprecipitation of integrins and PMP22. For the coimmunoprecipitation experiments, a previously established procedure was used (Gudz et al., 2002). Briefly, sciatic nerves from P21 +/+ mice were lysed in immunoprecipitation (IP) buffer $(0.15 \mathrm{M} \mathrm{NaCl}, 0.05 \mathrm{M}$ Tris, $0.5 \mathrm{~mm}$ EDTA, pH 7.5, $1 \%$ Triton X-100, $0.05 \%$ SDS, and $0.2 \%$ bovine serum albumin) supplemented with complete protease inhibitor (Roche, Indianapolis, IN) and $500 \mu \mathrm{M}$ phenylmethylsulfonyl fluoride (SigmaAldrich). Lysates from PMP22-/- mice were analyzed in parallel as a negative control. After centrifugation, pelleted material was solubilized in IP buffer with $2.5 \%$ SDS and combined with the supernatant (final SDS volume, $0.3 \%)$. After a second centrifugation, protein lysate supernatants $(1 \mathrm{mg} / \mathrm{ml})$ were precleared by incubation with nonspecific rabbit or rat serum, followed by incubation with protein A-Sepharose (Amersham Biosciences, Piscataway, NJ) or protein G-agarose (Santa Cruz Biotechnology, Santa Cruz, CA), respectively. The supernatants were then incubated with rabbit polyclonal anti-PMP22, anti- $\beta 4$ integrin, and anti-laminin or rat monoclonal anti- $\alpha 6$ integrin antibodies, and the antibody-antigen complexes were captured with either protein 
A-Sepharose or protein G-agarose. Immunoprecipitates were eluted by boiling in SDS gel sample buffer with $2 \% \beta$-mercaptoethanol (Bio-Rad). Total protein lysates and immunoprecipitates were separated on $10 \%$ acrylamide gels, blotted to polyvinylidene difluoride membrane (BioRad), blocked with 5\% nonfat dry milk in PBS-T buffer (10 mm Tris, 150 $\mathrm{mm} \mathrm{NaCl}$, and $0.1 \%$ Tween $20, \mathrm{pH} 7.4$ ), and subsequently probed with the appropriate antibody [polyclonal anti-PMP22 (1:1000), anti- $\beta 4$ integrin (1:1000), anti-laminin (1:10,000), and mouse monoclonal $\beta$-dystroglycan (1:1000); NovoCastra, Newcastle, UK]. Bound antibodies were visualized using the enhanced chemiluminescence kit, as above.

Cell-surface labeling. Myelinating rat DRG-SC cocultures were rinsed with PBS containing $0.1 \mathrm{mM} \mathrm{CaCl}_{2}$ and $1 \mathrm{mM} \mathrm{MgCl}_{2}$, supplemented with complete protease inhibitor (Roche) and $500 \mu \mathrm{M}$ phenylmethylsulfonyl fluoride (Sigma-Aldrich) (PBS-CM) (Gudz et al., 2002). After incubation with $2 \mathrm{~mm}$ Sulfo-NHS-LC-biotin (Pierce) in PBS-CM for $1 \mathrm{~h}$ at $4^{\circ} \mathrm{C}$, the samples were washed with PBS and $0.1 \mathrm{~m}$ Tris- $\mathrm{HCl}$ and solubilized in IP buffer, as above. After centrifugation, strepavidin-agarose beads (Sigma-Aldrich) were added to the supernatant for $3 \mathrm{~h}$ at $4^{\circ} \mathrm{C}$. The beads were collected by brief centrifugation and washed in IP buffer. The biotin-avidin protein complexes were dissociated from the beads by heating in SDS and $\beta$-mercaptoethanol-containing gel sample buffer. The eluted proteins were analyzed on $12.5 \%$ acrylamide gels and blotted with polyclonal rabbit anti-PMP2 2 and anti- $\beta 4$ integrin antibodies and monoclonal mouse anti-actin (Sigma-Adlrich).

Protein interaction studies in clone A cells. Clone A cells, originally isolated from a poorly differentiated colon adenocarcinoma (Dexter et al. 1979), were a kind gift from Dr. A. Mercurio (Beth Israel Medical Center, Boston, MA). Cells were maintained in RPMI medium supplemented with $10 \%$ fetal calf serum, $50 \mu \mathrm{g} / \mathrm{ml}$ penicillin, $50 \mathrm{U}$ of streptomycin (Sigma-Aldrich), $5 \mathrm{~mm}$ HEPES, and $200 \mu \mathrm{M}$ L-glutamine (Invitrogen). The human PMP22 (a kind gift from Dr. C. Huxley, Imperial College School of Science, Technology, and Medicine, London, UK) open reading frame, tagged with a myc-epitope in the second extracellular loop, was inserted into the pLNCX2 retroviral vector (Clontech, Palo Alto, $\mathrm{CA}$ ), under the control of the cytomegalovirus promoter. Forty-eight hours after transfection with Lipofectamine and PLUS reagent (Invitrogen, Carlsbad, CA), samples were processed for double immunolabeling, as described above, except that cells were permeabilized with $0.2 \%$ Triton X-100/PBS for $15 \mathrm{~min}$ at room temperature and incubated with polyclonal rabbit anti-myc (Santa Cruz Biotechnology) and monoclonal mouse anti- $\beta 4$ integrin (Ancell Corporation, Bayport, MN) antibodies. For the coimmunoprecipitation experiments, monoclonal mouse antimyc (Santa Cruz Biotechnology) and polyclonal rabbit anti- $\beta 4$ integrin antibodies were used.

\section{Results}

Phenotype of PMP22-deficient LacZ mice

Targeted deletion of the $p m p 22$ gene was accomplished using the VelociGene technology (Valenzuela et al., 2003). This approach circumvents potential complications of previous gene silencing technologies, such as targeted disruption, which may allow for alternative splicing and some translation of PMP22. For this mouse model, the first two coding exons of pmp22, exons 2 and 3 (Fig. 1A), encoding the first transmembrane segment, were replaced with the lac $Z$ reporter in tandem with the neo selection gene (Fig. $1 B$ ). The entire $p m p 22$ coding sequence was not deleted because of concerns that removal of the large intron between exons 3 and $4(\sim 17,000 \mathrm{bp})$ may include regulatory elements, which could affect the expression pattern of the lac $Z$ reporter. In this design, the lac $Z$ gene is driven by the $p m p 22$ promoters, allowing for high-resolution analysis of the $\beta$-gal protein throughout the organism. To determine the genotypes of the mice, genomic DNA is blotted with a probe that contains a portion of the mouse pmp22 and the neomycin resistance gene (Fig. $1 C)$. In wild-type $(+/+)$ and heterozygote $(+/-)$ samples, a 2.2 $\mathrm{kb}$ fragment, indicative of the endogenous $p m p 22$ gene, is detected. The mutant allele is identified as a $7.6 \mathrm{~kb}$ band in $+/-$ and
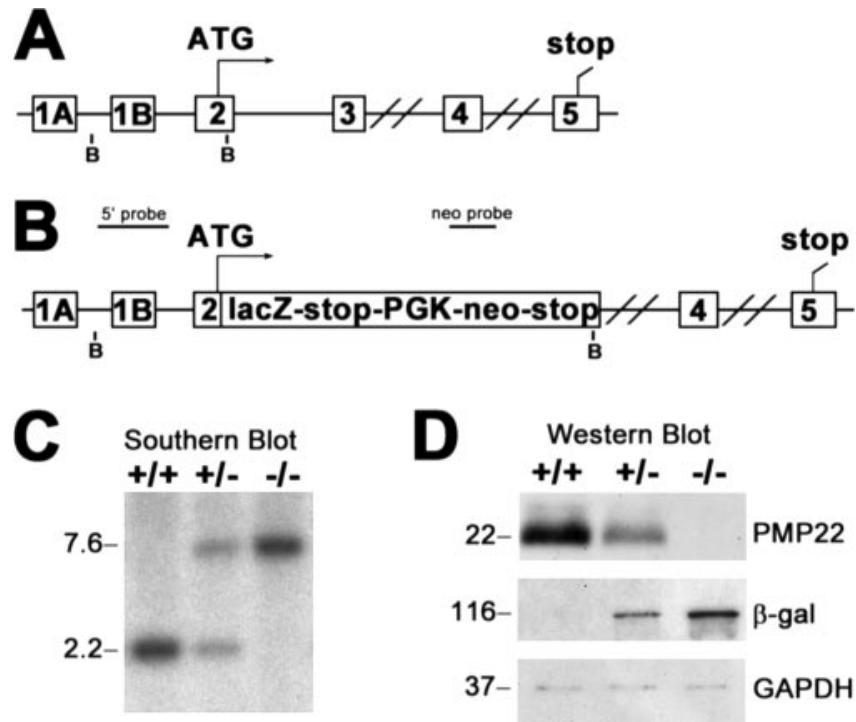

Figure 1. $A$, Schematic representation of the targeting strategy. The genomic structure of the mouse pmp22, showing the alternatively used exons $1 \mathrm{~A}$ and $1 \mathrm{~B}$, which are preceded by promoters 1 and 2, respectively, is shown. The double bars between exons 3 and 4 and exons 4 and 5 indicate 16.6 and $7.0 \mathrm{~kb}$ intronic sequences, respectively. $\boldsymbol{B}$, Diagram of the pmp22-lac $Z$ construct. The first two coding exons of pmp22 (exons 2 and 3) were replaced with the lacZ reporter, followed by a strong transcription termination signal, the $P G K$-neo gene, and a second stop signal. BamHI restriction sites $(\boldsymbol{B})$ and locations of the PMP22 (5' probe) and neo probes are shown $(\boldsymbol{A}, \boldsymbol{B})$. $\boldsymbol{C}$, Southern blot analysis of genomic DNA digested with BamHI from wild type $(+/+)$, heterozygous $(+/-)$, and homozygous PMP22 knock-out $(-/-)$ littermates. The endogenous allele is detected as a $2.2 \mathrm{~kb}$ fragment, whereas the mutant allele yields a $7.6 \mathrm{~kb}$ fragment. $\boldsymbol{D}$, Western blot analyses of sciatic nerve lysates (7.5 $\mu \mathrm{g} /$ lane) from adult $+/+$, $+1-$, and $-1-$ mice with anti-PMP22 and anti- $\beta$-gal antibodies. Anti-GAPDH is shown as a loading control. Molecular mass in kilobases $(\boldsymbol{C})$ and kilodaltons $(\boldsymbol{D})$ is shown on the left.

homozygous knock-out (-/-) samples. In accordance, Western blot analysis on entire sciatic nerve lysates confirms the expression of PMP2 2 in adult $+/+$ mice, with lower and undetectable levels in $+/-$ and $-/-$, respectively (Fig. $1 D$ ). $\beta$-gal reporter expression is reciprocal of PMP22, with the highest levels in the - I- nerves. To monitor equal protein loading, the blot was reprobed with an anti-GAPDH antibody.

Expression of the $\beta$-gal reporter was first examined on sections of heterozygote embryos at E15 (Fig. 2). Detected as a blue reaction product, $\beta$-gal is expressed broadly, with robust staining in the lung and intestines (Fig. $2 A$ ). At higher magnification, $\beta$-gal is evident in the rhombencephalic and mesencephalic neuroepithelium (Fig. $2 B$ ), the DRGs (Fig. 2C, arrow), the skeletal muscle (Fig. 2C, asterisk), and the cartilage of the vertebrae (Fig. $2 C$, arrowhead). The reporter is also prominent at the aortic arch of the heart, a previously unrecognized area for the expression of PMP22 (Fig. 2D, arrow). Fig. 2, E and F, shows a higher magnification of the lungs and the intestines, respectively. These results are in agreement with previous reports on the broad tissue distribution of the PMP22 mRNA during murine development (Baechner et al., 1995; Parmantier et al., 1995, 1997; Taylor et al., 1995) and validate the specificity of our targeting design.

Next, we investigated the expression of $\beta$-gal in adult heterozygous transgenic mice (Fig. 3). Many non-neural tissues remain positive for the reporter, including the lungs, intestines, gallbladder, kidneys, urinary bladder, reproductive organs, and stomach (data not shown). Particularly, the cartilage of the ribs (Fig. 3A) and the aortic arch (Fig. 3B) display high levels of $\beta$-gal expression. On whole mounts of the brain, the deep nuclei of the brainstem (Fig. 3C, arrows) and the cranial nerves (Fig. 3C, 
arrowheads) are reactive. In addition, the high abundance of PMP22 in the PNS is confirmed on spinal cord preparations, which display robust $\beta$-gal reactivity in the peripheral nerves (Fig. 3D).

Phenotypically, heterozygous PMP22deficient mice should model hereditary neuropathy with liability to pressure palsies (HNPP), which is commonly associated with deletion of one copy of the PMP22 gene (Chance et al., 1993). Homozygous PMP22-deficient mice are predicted to have a more severe neuropathy similar to CMT1A (Adlkofer et al., 1995). Indeed, when the mice are held by the base of the tail, wild-type adults splay their hindlimbs and relax their forelimbs (Fig. $3 E,+/+)$. In comparison, homozygous PMP22-deficient mice manifest visible signs of motor deficits, including clasped hindlimbs, tremor, and hindered gait (Fig. $3 \mathrm{E},-/-$ ), which become noticeable by 2 weeks of age. As the animals age, distal muscle weakness advances to hind-limb paralysis. Heterozygous mice are less affected during the first 2 months of postnatal development but display various severities of visible motor deficits by 5 months of age. PMP22 - / - mice are less capable of mating and show postnatal growth retardation compared with $+/+$ littermates. By 3 weeks of age, PMP22-/- mice weigh $\sim 2 \mathrm{~g}$ less than their $+/+$ littermates (+/+: $9.7 \mathrm{~g}, n=7 ;-/-: 7.7 \mathrm{~g}, n=8 ; p<$ $0.005)$. On morphological examination, the sciatic nerves from P21 -/ - mice reveal tomacula, sausage-like thickenings of myelin (Fig. 3F, arrowhead). Paranodal tomacula are the most common; however, internodal myelin thickenings were also noted (data not shown). At 3 weeks of age, tomacula are less common in the sciatic nerves of heterozygous mice but increase in frequency as the animals grow older (our unpublished data; Adlkofer et al., 1995). Compared with young animals (Fig. $3 F$ ), our preliminary studies show fewer tomacula and an increase in demyelinating profiles in nerve samples from adult $-/-$ mice (data not shown). Because tomacula are the neuropathological hallmarks of HNPP (Meier and Moll, 1982), their presence in the nerves of affected mice further validates our model.

\section{Delayed myelination and altered SC-ECM interactions in the} absence of PMP22

During myelination, PMP22 is thought to play a role in the interactions between SCs and axons, possibly mediating myelin wrapping (Martini and Schachner, 1997). Therefore, sciatic nerves from genotyped $+/+$ and $-/-$ littermates between the ages of P3 and P18, within the period of active myelination, were fixed and processed for morphological examination (Fig. 4). Thick sections $(1 \mu \mathrm{m})$ of nerves from $\mathrm{P} 10+/+$ mice show the proper one-to- one axon-SC relationships and many well myelinated fibers (Fig. $4 A$ ). In comparison, in the absence of PMP22, there is a notable increase in the number of SCs that are halted in the promyelinating stage, where they have surrounded axons but have not begun wrapping them (Fig. $4 B, D$, arrowheads). At P10, $95 \pm 3 \%$ of defasciculated axons from $+/+$ mice are myelinated, whereas only $56 \pm 13 \%$ of axons from $-/-$ mice are $(n=3$ per genotype; $p<0.0005)$. In agreement with the detection of tomacula in teased nerve fibers (Fig. $3 F$ ), some axons are hypermyelinated (Fig. $4 B$, asterisks). After the exclusion of promyelinated and hypermyelinated profiles, we quantified axon and fiber diameters in multiple sections from P10, P13, and P18 littermates. At the ages examined, measurements of $>500$ axon-SC profiles per genotype revealed an $\sim 19 \%$ reduction in axon $(+/+, 3.37 \mu \mathrm{m}$; 

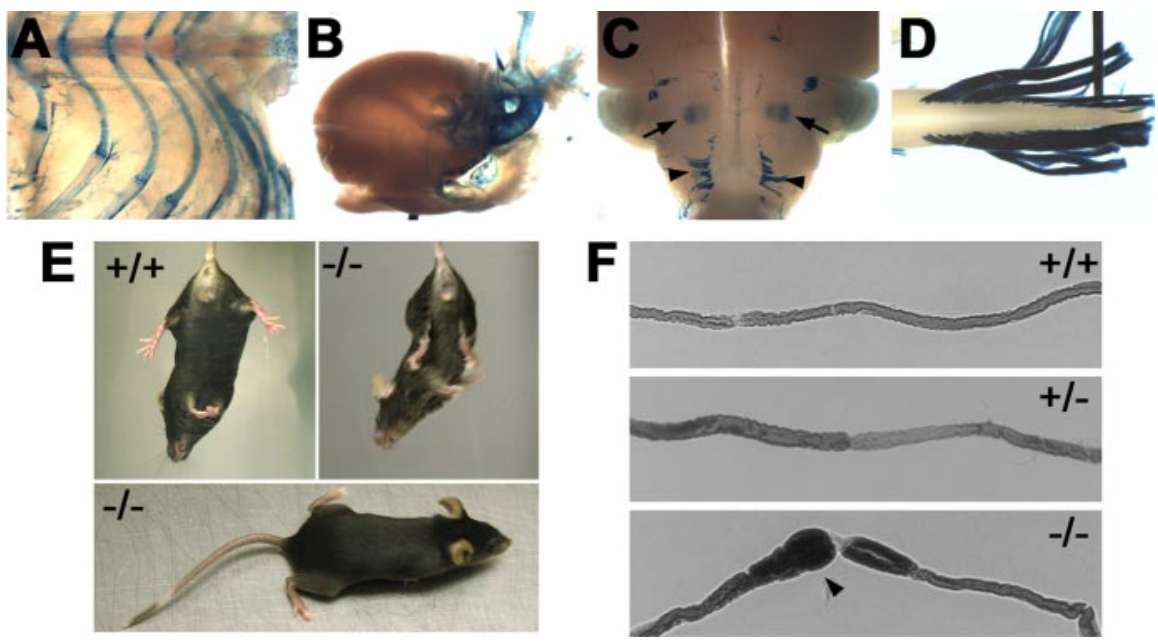

Figure 3. Phenotype of adult PMP22-deficient mice. $\boldsymbol{A}-\boldsymbol{D}$, Distinct $\beta$-gal expression is evident in the ribs $(\boldsymbol{A})$, aortic arch of the heart $(\boldsymbol{B})$, brainstem deep nuclei ( $\boldsymbol{C}$, arrows), cranial nerve roots ( $\boldsymbol{C}$, arrowheads), and the peripheral roots of a spinal cord preparation $(\boldsymbol{D})$. $\boldsymbol{E}$, Behavioral phenotypes of 3-month-old littermates. Wild type $(+/+)$ mice have splayed hindlimbs and relaxed forelimbs, whereas PMP22-deficient littermates $(-/-)$ clasp their hindlimbs and forelimbs close to their body (top right) and display gait abnormalities (bottom). $\boldsymbol{F}$, Teased nerve fibers from genotyped P21 littermates. Nerve fibers of PMP22 - / - mice exhibit frequent tomacula (arrowhead). Magnification, $40 \times$.

$-/-, 2.68 \mu \mathrm{m})$ and a $23 \%$ reduction in fiber $(+/+, 5.04 \mu \mathrm{m}$; $-/-, 3.84 \mu \mathrm{m})$ diameters in nerves of $-/-$ mice $(n=5)$ compared with $+/+$ littermates $(n=4)(p<0.0005$ for both $)$. As the result of these changes, the G-ratios in the affected samples are increased by $\sim 5 \%(+/+, 0.668 ;-/-, 0.701 ; p<0.005)$, indicating dysmyelination.

Ultrathin sections of the same samples from P10 +/ + mice show tightly adhered SCs against their axons, and each axon-SC unit is surrounded by a basal lamina (Fig. $4 C$, inset, arrow). In comparison, pockets of loose basal lamina are prominent in cross sections of nerves from P10 $-/-$ mice (Fig. $4 D$, arrows). The boxed area in $4 D$ is magnified to illustrate the excess, loose basal lamina around a particular SC-axon profile (Fig. $4 F$, arrow). In some instances, bare axons with pockets of basal lamina are observed (Fig. 4D, a), suggesting that the SCs have retracted their processes. SC profiles, as judged by the presence of a surrounding basal lamina, with irregular cytoplasmic processes, are also present (Fig. $4 D$, open arrowhead). The described morphological alterations persist throughout the first 3 weeks of postnatal development (Fig. $4 E-G$, arrows) and can also be seen in samples from adult mice (data not shown).

\section{$\beta 4$ integrin levels are reduced in sciatic nerves of PMP22-/- mice}

To investigate the molecular changes associated with the altered basal lamina profiles, nerves from P10 genotyped littermates were processed for analyses with anti-basal lamina and SC outer surface (abaxonal) protein antibodies, including laminin and integrins (Fig. 5). As described previously (Einheber et al., 1993), $\beta 4$ integrin is mainly localized to the outer membrane of SCs in nerves of $\mathrm{P} 10+/+$ mice (Fig. $5 A$, arrow). In comparison, $\beta 4$-like staining intensity is notably reduced in the homozygous PMP22 knock-out sample, and the basal lamina-like pattern is discernable only occasionally (Fig. 5B, arrow). Likewise, in nerves of $+/+$ mice, $\beta 1$ integrin antibodies label the outer SC membrane (Fig. $5 C$, arrow), whereas in the absence of PMP22, $\beta 1$-like immunoreactivity is patchy and less distinct (Fig. 5D). Laminin, a major protein component of the SC basal lamina, is detected around each axon-SC unit, adjacent to the abaxonal SC mem- brane in normal nerves (Fig. $5 E$ ). Similar to the integrins (Fig. $5 B, D$ ), in sections from PMP22-/- mice, laminin-like immunoreactivity appears less organized, and thickenings of the basal lamina are seen (Fig. 5F, arrowheads). Nonspecific rat or rabbit sera do not label the nerve sections (Fig. 5A, $B, E, F$, insets). The nerve cross sections shown in Figure 5 are costained with the Hoechst nuclear dye, which reveals elevated cell density in the absence of PMP22. Quantification of independent samples from three mice per genotype shows an $\sim 1.5$-fold increase in nuclei in affected nerves $(p<0.05)$. This finding agrees with a previous report on increased cell density at P10 in nerves of homozygous PMP22-deficient mice (Sancho et al., 2001).

To substantiate the reduction in $\beta 4$ like immunoreactivity in affected samples, entire sciatic nerve lysates from P10 littermates were blotted with the indicated antibodies (Fig. 5G). In agreement with the immunolocalization studies (Fig. $5 A-F$ ), the levels of $\beta 4$ integrin are reduced in nerves of PMP22- -- mice, whereas $\beta 1$ integrin remains relatively constant. GAPDH is shown as a protein loading control. Because the mobility of laminin is similar to $\beta 4$ on SDS gels, a parallel blot was probed with anti-laminin antibody. As predicted from the immunostaining (Fig. $5 E, F$ ), the level of laminin is unaltered in nerves of PMP22-/ - mice. The reduction in the levels of $\beta 4$ integrin is consistent among several independent samples and at all ages tested, including P18 and adult (data not shown).

\section{PMP22 is in a complex with $\alpha 6 \beta 4$ integrin and laminin}

The reduction in $\beta 4$ integrin levels in the absence of PMP22 could suggest that the two proteins are in a complex. To investigate the potential interaction of $\beta 4$ integrin and PMP22, sciatic nerve lysates of 3 -week-old $+/+$ mice were immunoprecipitated with antibodies against candidate proteins. Subsequently, the immunoprecipitates were analyzed by Western blots for the indicated binding partners, as shown at the right of each Western blot. First, total nerve lysates (T lane) were precleared (PC lane) with nonspecific rabbit IgGs and incubated with a rabbit anti- $\beta 4$ integrin antibody (Fig. $6 \mathrm{~A}$, left). Probing of the immunoprecipitate with the indicated antibodies, after electrophoretic separation, identifies not only $\beta 4$ integrin but also PMP22 in the precipitate. In a reciprocal experiment, PMP22 was immunoprecipitated and analyzed for $\beta 4$ integrin (Fig. $6 A$, right). As before, the blot was reprobed with anti-PMP22 antibody to verify the precipitation of PMP22. These coimmunoprecipitation experiments indicate that PMP22 is in a complex with $\beta 4$ integrin. In myelinating peripheral nerves, $\beta 4$ is known to interact with $\alpha 6$ integrin and laminin (Lee et al., 1992; Previtali et al., 2001); therefore, we investigated whether laminin could be detected in the immunoprecipitate (Fig. $6 \mathrm{~A}$, right). Probing with anti-laminin reveals that it coprecipitates with PMP22, whereas $\beta$-dystroglycan, another laminin receptor in peripheral nerves (Scherer and Arroyo, 2002), does not (Fig. 6A, right). The two bands on the anti-laminin Western blot of the PMP22 immunoprecipitate may represent differential mobilities of the $\sim 200 \mathrm{kDa}$ 
$\beta$ and $\gamma$ chains that do not always resolve in the total or on the reprobes.

To substantiate the interaction of PMP22 with the integrin protein complex, the nerve lysates were incubated with anti- $\alpha 6$ integrin or anti-laminin antibodies (Fig. 6B). Subsequent Western blot analyses of the immunoprecipitates identify PMP22 in the pull-down fractions. Because the anti- $\alpha 6$ antibody does not work on blots of denatured samples, the $\alpha 6$ precipitate was reprobed for $\beta 4$, the binding partner of $\alpha 6$ in peripheral nerves (Fig. $6 B$, left). Compared with the integrins and laminin, PMP22 is more abundant in entire nerve lysates; therefore, when only 1 $\mu \mathrm{g}$ of total protein is analyzed (T lanes), PMP22 is readily detected, whereas laminin and $\beta 4$ are barely visible on the reprobes (Fig. 6A-C, asterisks). However, laminin and $\beta 4$ are prominent when $20 \mu \mathrm{g}$ of entire nerve lysates are analyzed (Fig. $5 G)$. As a control for the specificity of the coimmunoprecipitation experiments, lysates from PMP22-/- mouse nerves were incubated with $\beta 4$ integrin antibodies (Fig. $6 C$ ). In agreement with the reduced levels of $\beta 4$ integrin in affected nerves, there is a faint enrichment in $\beta 4$ integrin in the pull-down fraction, yet PMP22 is not detected. Together, these studies indicate that a fraction of PMP22 is in complex with $\alpha 6 \beta 4$ integrin and laminin in nerves of $+/+$ mice.

In myelinating peripheral nerves, the expression levels of PMP22 and $\alpha 6 \beta 4$ integrin substantially increase during the first 2 weeks of postnatal development (Notterpek et al., 1999; Previtali et al., 2001); however, the potential colocalization of these molecules has not been examined. To corroborate the interaction of PMP22 with the integrin complex, nerve samples from $+/+$ mice and myelinating DRG neuron-SC cocultures were studied (Fig. 7). Although the fixation conditions are not optimal for the codetection of the two antigens, on cross sections of sciatic nerves from 3-month-old mice, a portion of PMP22-like staining overlaps with $\beta 4$ integrin (Fig. 7A). On the merged single plane confocal image, the yellow color indicates the colocalization of PMP22 with $\beta 4$ integrin at the abaxonal SC membrane (Fig. 7A, arrows). Normal rat or rabbit serum, used as controls of specificity, do not stain the nerve sections (Fig. 7A, insets). Additionally, the steady-state levels of $\beta 4$ integrin and PMP22 increase concomitantly during the first 3 weeks of postnatal development (Fig. $7 B$, arrows). The arrowhead on the PMP22 Western blot identifies a nonspecific band that is reactive with our polyclonal antibody. Because integrins are established cell-surface receptors of SCs (Previtali et al., 2001), the fraction of PMP22 that is in complex with the integrins should also be accessible to cell-surface labeling. Therefore, myelinating DRG-SC cocultures were incubated with Sulfo-NHSLC-biotin and subsequently precipitated with strepavidin (Fig. 7C). $\beta 4$ integrin, as expected, and PMP22 are detected in the pull-down fraction, which represents the cell-surface pool of these molecules. Actin, a known intracellular protein, served as a negative control. Together, these studies indicate that PMP22 is coexpressed in time and locale with $\beta 4$ integrin in myelinating nerves and DRG-SC cocultures.

Next, we asked whether PMP22 may form a complex with $\beta 4$ integrin in non-neural samples as well (Fig. 8). A human colon adenocarcinoma cell line, termed clone $A$, is known to express high levels of $\alpha 6 \beta 4$ integrin and is amenable to transfection (Dexter et al., 1979; Lotz et al., 1990). Clone A cells were transfected with epitope (myc)-tagged human PMP22 (hPMP-myc) and analyzed with anti-myc and anti- $\beta 4$ integrin antibodies (Fig. 8). In a cluster of transfected cells, hPMP-myc is targeted to the $\beta 4$ integrin-positive cell membrane, resulting in a yellow color on the merged image (Fig. 8A-C, arrows). Nontransfected cells in the periphery of the image act as an internal control for the antimyc antibody (Fig. 8B,C). In parallel, clone A cells transfected with either vector alone or hPMP-myc were lysed in IP buffer and incubated with the indicated antibodies (Fig. 8D). When lysates 

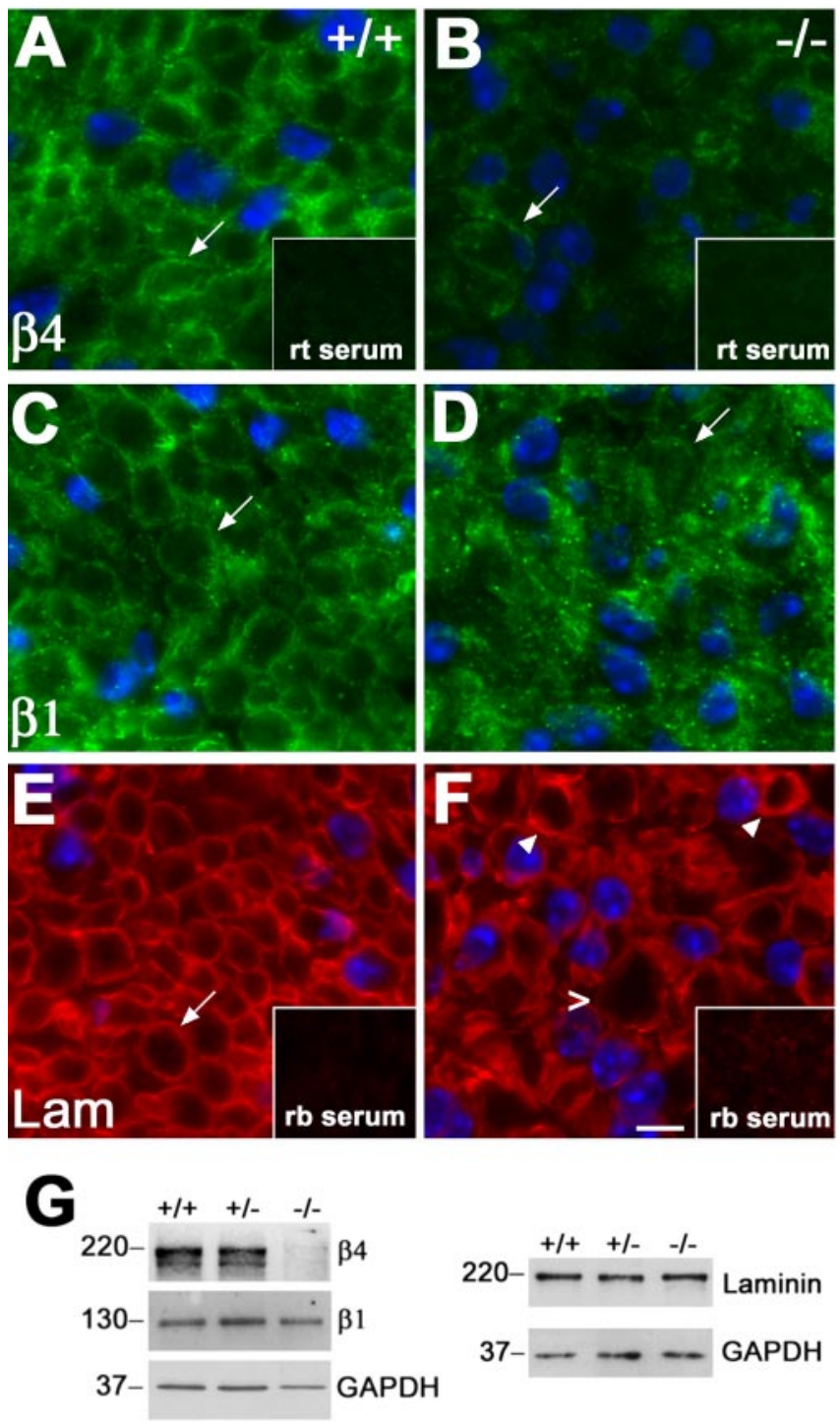

Figure 5. Decreased levels of $\beta 4$ integrin in nerves of PMP22-deficient mice. $\boldsymbol{A}-\boldsymbol{F}$, Cryosections of sciatic nerves from $+/+(\boldsymbol{A}, \boldsymbol{C}, \boldsymbol{E})$ and PMP22- $-/-(\boldsymbol{B}, \boldsymbol{D}, \boldsymbol{F})$ mice were immunostained with monoclonal rat (rt) anti- $\beta 4$ integrin $(\boldsymbol{A}, \boldsymbol{B})$, anti- $\beta 1$ integrin $(\boldsymbol{C}, \boldsymbol{D})$, or polyclonal rabbit $(\mathrm{rb})$ anti-laminin $(\operatorname{Lam})(\boldsymbol{E}, \boldsymbol{F})$ antibodies. In nerves of P10 $+/+$ mice, $\beta 4$ and $\beta 1$ integrin are detected at the abaxonal $S C$ surface $(\boldsymbol{A}, \boldsymbol{C}$, arrows). In comparison, abaxonal integrin-like staining is only discernable around a fraction of the fibers in the $-/-$ samples ( $\boldsymbol{B}$, $D$, arrows). In addition, when the images were collected at the same exposure times, the level of $\beta 4$-like immunoreactivity was reduced (compare $\boldsymbol{A}, \boldsymbol{B}$ ). Laminin was detected at the SC basal lamina in $+/+(\boldsymbol{E}$, arrow) and $-/-(\boldsymbol{F})$ nerves, with thickened basal lamina (arrowheads) and a tomaculum (open arrowhead) marked in the affected sample ( $\mathbf{F})$. Nonspecific rat $(\boldsymbol{A}, \boldsymbol{B}$, inset) and rabbit $(\boldsymbol{E}, \boldsymbol{F}$, inset) sera serve as controls for staining specificity. Scale bar, $5 \mu \mathrm{m} . \boldsymbol{G}$, Sciatic nerve lysates (20 $\mu \mathrm{g} /$ lane) from $\mathrm{P} 10+/+,+/-$, and $-/-$ mice were analyzed with polyclonal rabbit anti- $\beta 4$ integrin and anti-laminin and monoclonal rat anti- $\beta 1$ integrin antibodies. The blots were reprobed with monoclonal mouse anti-GAPDH antibody as a protein loading control. Molecular mass is in kilodaltons.

of vector control cultures are immunoprecipitated with the $\beta 4$ integrin antibody and blotted with an anti-myc, no bands are visible. In comparison, when the same experiment is performed in PMP-myc-transfected cells, hPMP-myc is coimmunoprecipitated with $\beta 4$ integrin (Fig. $8 D$, Western blot with myc, arrow). To confirm the identity of the myc-immunoreactive band as PMP22, one-half of the immunoprecipitate was treated with PNGase F to remove the carbohydrate moiety of PMP22. As described previously (Pareek et al., 1997), after PNGase F treat-
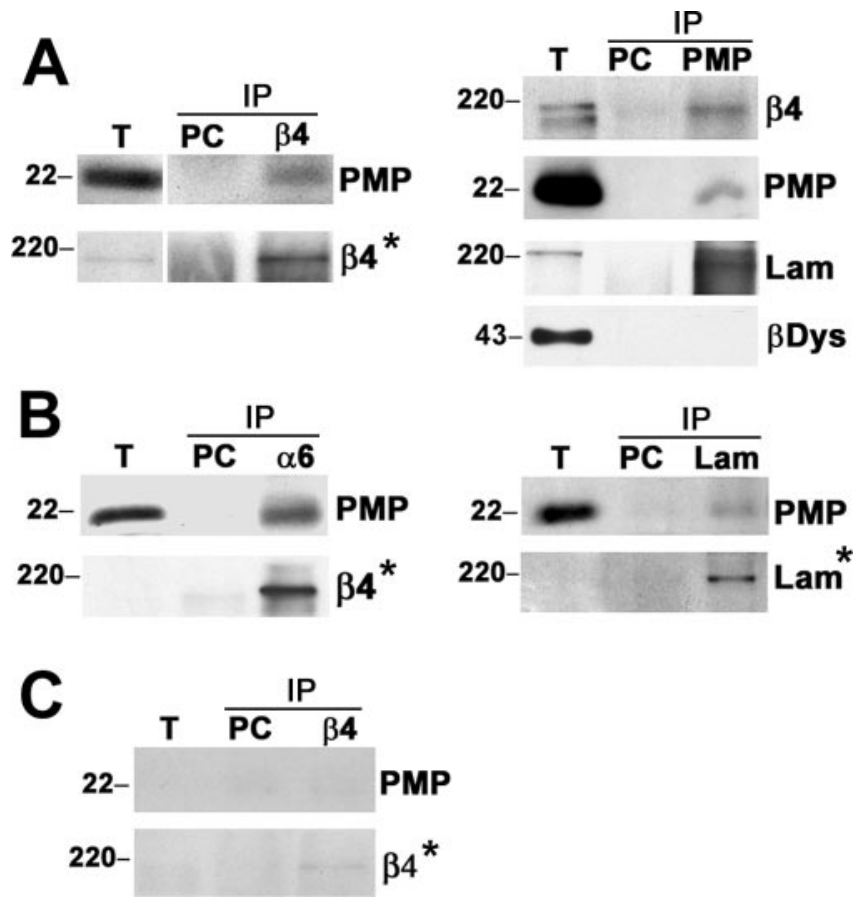

Figure 6. PMP22 is in a complex with $\alpha 6 \beta 4$ integrin and laminin. Sciatic nerve lysates (T lanes) from $\mathrm{P} 21+1+$ mice were processed for IP, after preclearing (PC lanes) with nonspecific Igs of the appropriate isotype. Lysates were incubated with polyclonal rabbit anti- $\beta 4$ integrin $(\boldsymbol{A}$, left, $\boldsymbol{C})$, anti-PMP22 ( $\boldsymbol{A}$, right), monoclonal rat anti- $\alpha 6$ integrin ( $\boldsymbol{B}$, left), or polyclonal rabbit anti-laminin ( $\boldsymbol{B}$, right) antibodies, and captured immunoprecipitates were probed for the indicated proteins $(\boldsymbol{A}-\boldsymbol{C})$ as designated at the right of each blot. On reprobes (marked with asterisks), after stripping the membranes, the anti- $\beta 4$ integrin and anti-laminin antibodies did not work efficiently when $1 \mu \mathrm{g} /$ lane total (T) nerve protein was analyzed. IP with anti- $\beta 4$ integrin on nerve lysates of homozygous PMP22-deficient mice is shown as a negative control (C). Molecular mass is in kilodaltons. PMP, PMP22; Lam, laminin; $\beta$ Dys, $\beta$-dystroglycan.

ment, the $\sim 22 \mathrm{kDa}$ band shifts to $18 \mathrm{kDa}$, which represent the core PMP22 peptide (Fig. 8D, Western blot with myc, arrowhead). The blots were reprobed with $\beta 4$ integrin to show that $\beta 4$ integrin is efficiently immunoprecipitated from both vector control and hPMP-myc-expressing cultures. After PNGase F treatment, the mobility of $\beta 4$ is also changed from $\sim 200 \mathrm{kDa}$ to 190 $\mathrm{kDa}$ (Fig. $8 D$, Western blot with $\beta 4$, arrow and arrowhead, respectively) (Sonnenberg et al., 1988). These results indicate that PMP2 2 and $\beta 4$ integrin are in a complex in a variety of cell types.

\section{Discussion}

Understanding the role of PMP22 in the cell membrane has been hindered by lack of knowledge on interacting proteins, particularly molecules with signaling potential. In the current study, we characterized a novel PMP22-deficient mouse model that led us to identify PMP22 as a binding partner for the $\alpha 6 \beta 4$ integrin and laminin complex. Analyses of heterozygous PMP22-deficient mice revealed broad tissue distribution of the $\beta$-gal reporter and an HNPP-like neuropathic phenotype. In nerves of homozygous knock-out mice, we detected loose SC basal lamina and reduced levels of $\beta 4$ integrin, suggesting a role for PMP22 in the stabilization of integrins in the cell membrane. Indeed, coimmunoprecipitation experiments from nerves of $+/+$ mice and clone $\mathrm{A}$ human colonic carcinoma cells show that PMP22 is in a complex with $\alpha 6 \beta 4$ integrin and laminin.

The VelociGene technology used in this study uses targeting vectors based on bacterial artificial chromosomes that can precisely replace the gene of interest with a reporter, allowing for 
high-resolution localization of target gene expression (Valenzuela et al., 2003). The $\beta$-gal reporter studies described here confirm and extend previous studies on the expansive tissue distribution of PMP22 mRNA during embryonic development and in the adult rodent (Baechner et al., 1995; Parmantier et al., 1995, 1997). The detection of $\beta$-gal in the aortic arch of the heart (Fig. 2D) agrees with our findings on the expression of PMP22 in a variety of vascular tissue (Notterpek et al., 2001; Roux et al., 2004). Other non-neural tissues that show robust reporter expression include the lungs, intestines, and cartilage. The function of PMP22 at these locations is not yet known, although frequent amplification and overexpression of PMP22 in high-grade osteosarcoma has been reported recently (Huhne et al., 1999; van Dartel and Hulsebos, 2004). In contrast, the levels of PMP22 transcripts were reduced by $\sim 20$-fold in urethane-induced mouse lung tumors (Re et al., 1992). These reports indicate that PMP22 may play crucial roles in a variety of tissues, likely regulating cell proliferation and differentiation. Nonetheless, whereas homozygous PMP22-/- mice consistently show postnatal growth retardation, the gross pathological alterations are limited to myelinated peripheral nerves. These data may indicate a particular sensitivity of SCs to PMP22 expression and/or the existence of compensatory mechanisms in other tissues.

Phenotypically, PMP22-/- mice display a severe neuropathy that is apparent by the third week after birth. The peripheral nerves contain an excess number of SCs and show delayed myelination, as well as hypermyelination of individual axons (Figs. 3, 4). These abnormalities are in agreement with data from young PMP22deficient (Adlkofer et al., 1995) and PMP22 overexpressor (Magyar et al., 1996; Robaglia-Schlupp et al., 2002) mice. In nerves of PMP22-deficient and overproducer mice, prominent pockets of basal laminas surrounding hypomyelinated axons were also described previously (Magyar et al., 1996; Adlkofer et al., 1997), but the molecular mechanisms underlying these changes were not addressed. Similarly, inaccurate SC-axon interactions and redundant basal lamina were noted in Trembler J mice (Robertson et al., 1997, 1999), which carry a Leu16Pro mutation in the first transmembrane domain of PMP22 (Suter et al., 1992). The described abnormalities in the nerves of $-/-$ mice (Figs. $4-7$ ), together with our findings in an epithelial wound healing model (Roux et al., 2005), suggest a direct role for PMP22 in mediating the interactions between cells and the ECM. Cell-matrix interactions can influence cell shape, which is profoundly modulated by PMP22 (Brancolini et al.,
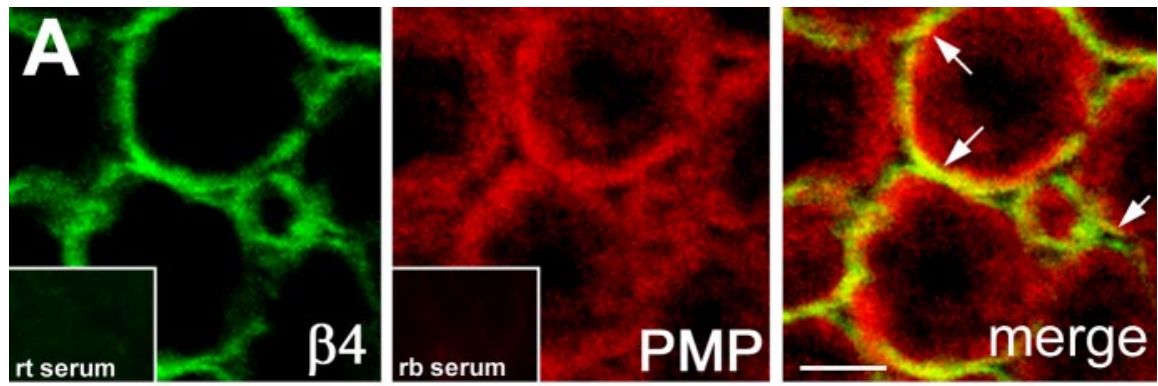

B

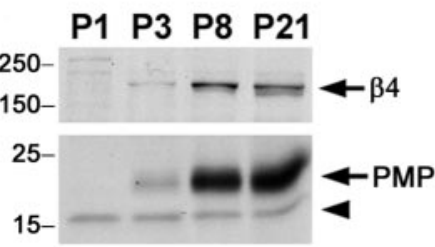

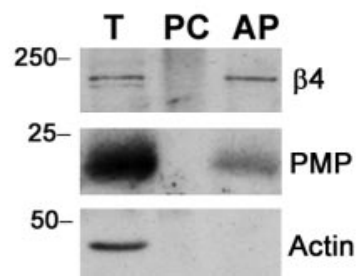

Figure 7. Coexpression of PMP22 and integrins during myelination. $\boldsymbol{A}$, Sciatic nerve cryosections from 3-month-old $+/+$ mice were labeled with monoclonal rat anti- $\beta 4$ and polyclonal rabbit anti-PMP22 antibodies and examined by confocal microscopy. The merged single plane image reveals the partial colocalization (merge, yellow) of $\beta 4$ integrin (green) and PMP22 (red). Scale bar, $5 \mu \mathrm{m}$. Nonspecific rat (rt) and rabbit (rb) sera (bottom insets) serve as controls for staining specificity. $\boldsymbol{B}$, Entire protein lysates of P1, P3, P8, and P21 sciatic nerves (10 $\mu \mathrm{g} /$ lane) from $+/+$ mice were analyzed with anti-PMP2 2 and anti- $\beta 4$ integrin antibodies. The arrows indicate the migration of $\beta 4$ integrin at $\sim 200 \mathrm{kDa}$ (top) and of PMP22 at $\sim 22 \mathrm{kDa}$ (bottom), whereas the arrowhead marks a nonspecific immunoreactive band. C, Cell-surface biotinylation of myelinating DRG-SC cocultures identifies $\beta 4$ integrin and PMP22 in the avidin pull down (AP), from which actin is excluded. Total lysate (T) and agarose bead preclear (PC) fractions are also shown. Molecular mass is in kilodaltons. PMP, PMP22.
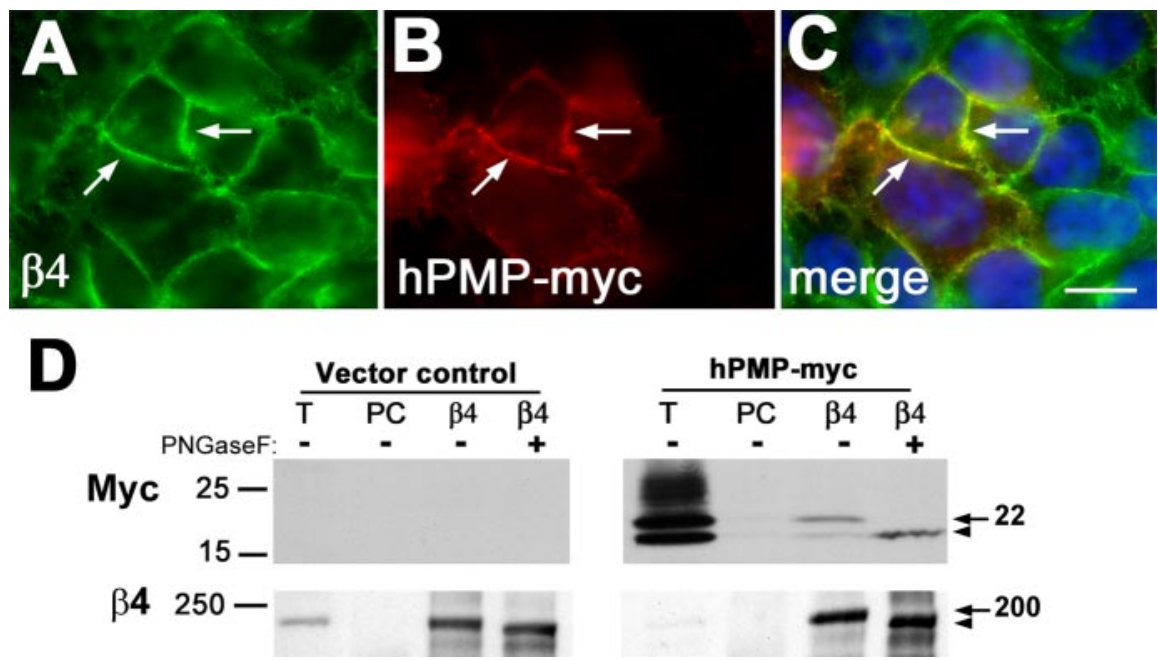

Figure 8. $\quad \mathrm{PMP} 22$ and $\beta 4$ integrin are coimmunoprecipitated from clone $A$ cells. $\boldsymbol{A}, \boldsymbol{B}$, Epitope (myc)-tagged hPMP22 was expressed in clone $A$ cells, and samples were double immunolabeled with anti- $\beta 4(\boldsymbol{A})$ and anti-myc $(\boldsymbol{B})$ antibodies. $\boldsymbol{C}$, As the merged image reveals, hPMP22 is targeted to the $\beta 4$ integrin-positive plasma membrane of the cells ( $\boldsymbol{A}-\boldsymbol{C}$, arrows). Scale bar, 10 $\mu \mathrm{m} . \boldsymbol{D}$, Vector control and hPMP-myc-expressing clone A cells were lysed and processed for IP with the indicated antibodies. The precipitates were subsequently probed for the marked proteins by Western blot. The arrows on the right indicate the overexpressed glycosylated PMP22 ( $\sim 22 \mathrm{kDa}$ ) and the endogenous $\beta 4$ integrin ( $\sim 200 \mathrm{kDa})$. The arrowheads point at the position of the deglycosylated $\sim 18$ and $\sim 190$ kDa forms. Molecular mass is in kilodaltons. T, Total lysate; PC, preclear.

1999; Roux et al., 2005). In fibroblasts and SCs, the overexpression of PMP22 induces membrane blebbing and regulates cell spreading (Brancolini et al., 2000), whereas in MDCK (Madin-Darby canine kidney) epithelial monolayers it leads to a flattened morphology (Roux et al., 2005). Changes in cells shape, as well as actin remodeling, are prerequisites for myelinogenesis in the PNS (Bunge et al., 1989; Fernandez-Valle et al., 1997). Therefore, based on the described biological effects of PMP22, it is expected that in its absence, SC differentiation and myelination are delayed (Fig. 4). 
Laminins are major components of the basal lamina and known mediators of SC differentiation, axon myelination, and regeneration in the PNS (Chen and Strickland, 2003). In agreement, the ablation of specific laminin chains alters SC proliferation, which in turn prevents the defasciculation and myelination of peripheral nerves (Colognato et al., 2005). In addition to integrins, laminins bind a variety of adhesive molecules that carry the L2/HNK1 carbohydrate adhesion recognition epitope (Schmidt and Schachner, 1998). PMP22 contains this epitope (Snipes et al., 1993); therefore, it may directly bind laminin. The glycosylation consensus sequence at asparagine 41 , which bears this epitope, is conserved among members of the PMP22 gene family and across species as distant as zebrafish (Taylor et al., 1995; Wulf et al., 1999). This carbohydrate modification of PMP22 is involved in the stabilization of PMP22 homodimers (Tobler et al., 1999) and in the cell spreading effects (Brancolini et al., 1999, 2000), but not in the trafficking of the protein to the SC membrane (Ryan et al., 2000), or in the interaction with protein zero (Hasse et al., 2004). The L2/HNK-1 epitope can also modulate the heterophilic interaction of some nervous system molecules, including $\alpha 1 \beta 1$ integrin and laminin (Pesheva et al., 1987; Lallier and BronnerFraser, 1992). Additional studies will determine whether PMP22 has the ability to directly bind laminin and whether this interaction depends on its carbohydrate moiety.

Similar to laminins, abnormal expression of integrins is associated with degenerative, inflammatory, and malignant disorders of the PNS, suggesting a key role for these molecules in nerve biology (Previtali et al., 2001). The $\alpha 6 \beta 1$ integrin dimer is prominent during the promyelinating stage, and its expression influences the migration of mouse SCs in vitro (Milner et al., 1997). The conditional disruption of $\beta 1$ integrin in SCs is associated with dysmyelination, loose, undulating basal lamina, and aberrant SC morphology (Feltri et al., 2002). The observed defects in the basal lamina of PMP22-/- nerves are comparable to those seen in this $\beta 1$ integrin-deficient model (Feltri et al., 2002). During early postnatal development, the $\alpha 6 \beta 4$ dimer becomes prevalent and is thought to be involved in myelinogenesis (Previtali et al., 2001). Because mice lacking $\beta 4$ integrin die shortly after birth, developmental studies of myelination are not feasible. However, DRG neuron cultures established from these mice can be induced to form myelin and have a continuous basal lamina, suggesting that $\beta 4$ integrin is not essential for myelination (Frei et al., 1999). Because $\alpha 6$ integrin can dimerize with $\beta 1$, in the absence of $\beta 4$, an $\alpha 6 \beta 1$ dimer may compensate for the $\alpha 6 \beta 4$ complex. Alternatively, $\beta 4$ integrin may have effects on myelination later in development that cannot be evaluated in the currently available $\beta 4-/-$ mice. In a recent report, $\alpha 7 \beta 1$ integrin was shown to be dispensable for peripheral nerve development and myelination (Previtali et al., 2003). Together, these findings indicate a redundancy in the integrin pathways and suggest that, under certain conditions, they may compensate for one another.

The recognition of PMP22 as a binding partner for the integrin/laminin complex is not unexpected. Previous studies have identified three PMP22-like tetraspan proteins: oligodendrocytespecific protein (OSP), epithelial membrane protein 2 (EMP-2), and proteolipid protein (PLP) that interact with integrins. OSP and OSP-associated protein form a complex with $\beta 1$ integrin and regulate the migration of oligodendrocytes (Tiwari-Woodruff et al., 2001). EMP-2, a PMP22 family member, interacts with $\alpha 6 \beta 1$ integrin and mediates the adhesion of $3 \mathrm{~T} 3$ fibroblasts to ECM proteins (Wadehra et al., 2002). PLP, a constituent of CNS myelin, forms a complex with $\alpha \mathrm{v}$ integrin, which appears to be important for the binding of fibronectin to oligodendrocytes ( $\mathrm{Gudz}$ et al., 2002). The interaction with the integrins provides PMP22 with the ability to modulate the cell-ECM communications, as well as intracellular events. Signaling between the ECM and the intracellular compartment is essential for SC myelination, as well as cellular differentiation and motility, in general. Independently, both integrins and PMP22 have been shown to modulate these physiological functions (Murgia et al., 1998; Rabinovitz and Mercurio, 1997; Danen and Sonnenberg, 2003; Roux et al., 2005); however, in the case of PMP22, the underlying molecular events are yet to be elucidated.

The results described here place PMP22 in a complex with $\alpha 6 \beta 4$ integrin and laminin in SCs and in a colonic carcinoma cell line. The identification of PMP22 as a binding partner for an integrin signaling complex provides a major step toward understanding the role of this disease-linked molecule in the nervous system and in non-neural cell types.

\section{References}

Adlkofer K, Martini R, Aguzzi A, Zielasek J, Toyka KV, Suter U (1995) Hypermyelination and demyelinating peripheral neuropathy in Pmp22deficient mice. Nat Genet 3:274-280.

Adlkofer K, Frei R, Neuberg DH, Zielasek J, Toyka KV, Suter U (1997) Heterozygous peripheral myelin protein 22-deficient mice are affected by a progressive demyelinating tomaculous neuropathy. J Neurosci 17:4662-4671.

Baechner D, Liehr T, Hameister H, Altenberger H, Grehl H, Suter U, Rautenstrauss B (1995) Widespread expression of the peripheral myelin protein-22 gene (PMP22) in neural and non-neural tissues during murine development. J Neurosci Res 42:733-741.

Brancolini C, Marzinotto S, Edomi P, Agostoni E, Fiorentini C, Muller HW, Schneider C (1999) Rho-dependent regulation of cell spreading by the tetraspan membrane protein Gas3/PMP22. Mol Biol Cell 10:2441-2459.

Brancolini C, Edomi P, Marzinotto S, Schneider C (2000) Exposure at the cell surface is required for gas3/PMP22 to regulate both cell death and cell spreading: implication for the Charcot-Marie-Tooth type $1 \mathrm{~A}$ and Dejerine-Sottas diseases. Mol Biol Cell 11:2901-2914.

Bunge MB, Bunge RP, Kleitman N, Dean AC (1989) Role of peripheral nerve extracellular matrix in Schwann cell function and in neurite regeneration. Dev Neurosci 11:348-360.

Bunge RP (1993) Expanding roles for the Schwann cell: ensheathment, myelination, trophism and regeneration. Curr Opin Neurobiol 3:805-809.

Chance PF, Alderson MK, Leppig KA, Lensch MW, Matsunami N, Smith B, Swanson PD, Odelberg SJ, Disteche CM, Bird TD (1993) DNA deletion associated with hereditary neuropathy with liability to pressure palsies. Cell 72:143-151.

Chen ZL, Strickland S (2003) Laminin gammal is critical for Schwann cell differentiation, axon myelination, and regeneration in the peripheral nerve. J Cell Biol 163:889-899.

Colognato H, ffrench-Constant C, Feltri ML (2005) Human diseases reveal novel roles for neural laminins. Trends Neurosci 28:480-486.

Danen EH, Sonnenberg A (2003) Integrins in regulation of tissue development and function. J Pathol 201:632-641.

Dexter DL, Barbosa JA, Calabresi P (1979) $N^{\prime}, N$-dimethylformamideinduced alteration of cell culture characteristics and loss of tumorigenicity in cultured human colon carcinoma cells. Cancer Res 39:1020-1025.

D’Urso D, Ehrhardt P, Muller HW (1999) Peripheral myelin protein 22 and protein zero: a novel association in peripheral nervous system myelin. J Neurosci 19:3396-3403.

Einheber S, Milner TA, Giancotti F, Salzer JL (1993) Axonal regulation of Schwann cell integrin expression suggests a role for alpha 6 beta 4 in myelination. J Cell Biol 5:1223-1236.

Eldridge CF, Bunge MB, Bunge RP, Wood PM (1987) Differentiation of axon-related Schwann cells in vitro. I. Ascorbic acid regulates basal lamina assembly and myelin formation. J Cell Biol 105:1023-1034.

Eldridge CF, Bunge MB, Bunge RP (1989) Differentiation of axon-related Schwann cells in vitro: II. Control of myelin formation by basal lamina. J Neurosci 9:625-638.

Feltri ML, Graus Porta D, Previtali SC, Nodari A, Migliavacca B, Cassetti A, Littlewood-Evans A, Reichardt LF, Messing A, Quattrini A, Mueller U, 
Wrabetz L (2002) Conditional disruption of beta 1 integrin in Schwann cells impedes interactions with axons. J Cell Biol 156:199-209.

Fernandez-Valle C, Gorman D, Gomez AM, Bunge MB (1997) Actin plays a role in both changes in cell shape and gene-expression associated with Schwann cell myelination. J Neurosci 17:241-250.

Frei R, Dowling J, Carenini S, Fuchs E, Martini R (1999) Myelin formation by Schwann cells in the absence of beta4 integrin. Glia 27:269-274.

Garcia A, Combarros O, Calleja J, Berciano J (1998) Charcot-Marie-Tooth disease type $1 \mathrm{~A}$ with $17 \mathrm{p}$ duplication in infancy and early childhood: a longitudinal clinical and electrophysiologic study. Neurology 50:1061-1067.

Gudz TI, Schneider TE, Haas TA, Macklin WB (2002) Myelin proteolipid protein forms a complex with integrins and may participate in integrin receptor signaling in oligodendrocytes. J Neurosci 22:7398-7407.

Hagedorn L, Suter U, Sommer L (1999) P0 and PMP22 mark a multipotent neural crest-derived cell type that displays community effects in response to TGF-beta family factors. Development 126:3781-3794.

Hasse B, Bosse F, Hanenberg H, Muller HW (2004) Peripheral myelin protein $22 \mathrm{kDa}$ and protein zero: domain specific trans-interactions. Mol Cell Neurosci 27:370-378.

Huhne K, Park O, Liehr T, Rautenstrauss B (1999) Expression analysis of the PMP22 gene in glioma and osteogenic sarcoma cell lines. J Neurosci Res 58:624-631.

Lallier T, Bronner-Fraser M (1992) Alpha 1 beta 1 integrin on neural crest cells recognizes some laminin substrata in a $\mathrm{Ca}^{2+}$-independent manner. J Cell Biol 119:1335-1345.

Lee EC, Lotz MM, Steele Jr GD, Mercurio AM (1992) The integrin alpha 6 beta 4 is a laminin receptor. J Cell Biol 117:671-678.

Lotz MM, Korzelius CA, Mercurio AM (1990) Human colon carcinoma cells use multiple receptors to adhere to laminin: involvement of alpha 6 beta 4 and alpha 2 beta 1 integrins. Cell Regul 1:249-257.

Magyar JP, Martini R, Ruelicke T, Aguzzi A, Adlkofer K, Dembic Z, Zielasek J, Toyka KV, Suter U (1996) Impaired differentiation of Schwann cells in transgenic mice with increased PMP22 gene dosage. J Neurosci 16:5351-5360.

Martini R, Schachner M (1997) Molecular bases of myelin formation as revealed by investigations on mice deficient in glial cell surface molecules. Glia 19:298-310.

Martini R, Zielasek J, Toyka KV, Giese KP, Schachner M (1995) Protein zero (P0)-deficient mice show myelin degeneration in peripheral nerves characteristic of inherited human neuropathies. Nat Genet 3:281-286.

Maycox PR, Ortuno D, Burrola P, Kuhn R, Bieri PL, Arrezo JC, Lemke G (1997) A transgenic mouse model for human hereditary neuropathy with liability to pressure palsies. Mol Cell Neurosci 8:405-416.

Meier C, Moll C (1982) Hereditary neuropathy with liability to pressure palsies. Report of two families and review of the literature. J Neurol 228:73-95.

Melendez-Vasquez CV, Einheber S, Salzer JL (2004) Rho kinase regulates Schwann cell myelination and formation of associated axonal domains. J Neurosci 24:3953-3963.

Milner R, Wilby M, Nishimura S, Boylen K, Edwards G, Fawcett J, Streuli C, Pytela R, ffrench-Constant C (1997) Division of labor of Schwann cell integrins during migration on peripheral nerve extracellular matrix ligands. Dev Biol 185:215-228.

Murgia C, Blaikie P, Kim N, Dans M, Petrie HT, Giancotti FG (1998) Cell cycle and adhesion defects in mice carrying a targeted deletion of the integrin beta4 cytoplasmic domain. EMBO J 17:3940-3951.

Naef R, Suter U (1998) Many facets of the peripheral myelin protein PMP22 in myelination and disease. Microsc Res Tech 41:359-371.

Nobbio L, Vigo T, Abbruzzese M, Levi G, Brancolini C, Mantero S, Grandis M, Benedetti L, Mancardi G, Schenone A (2004) Impairment of PMP22 transgenic Schwann cells differentiation in culture: implications for Charcot-Marie-Tooth type 1A disease. Neurobiol Dis 16:263-273.

Notterpek L, Tolwani RJ (1999) Experimental models of peripheral neuropathies. Lab Anim Sci 49:588-599.

Notterpek L, Snipes GJ, Shooter EM (1999) Temporal expression pattern of peripheral myelin protein 22 during in vivo and in vitro myelination. Glia 25:358-369.

Notterpek L, Roux KJ, Amici SA, Yazdanpour A, Rahner C, Fletcher BS (2001) Peripheral myelin protein 22 is a constituent of intercellular junctions in epithelia. Proc Natl Acad Sci USA 98:14404-14409.

Pareek S, Notterpek L, Snipes GJ, Naef R, Sossin W, Laliberte J, Iacampo S,
Suter U, Shooter EM, Murphy RA (1997) Neurons promote the translocation of peripheral myelin protein 22 into myelin. J Neurosci 17:7754-7762.

Parmantier E, Cabon F, Braun C, D’Urso D, Muller HW, Zalc B (1995) Peripheral myelin protein-22 is expressed in rat and mouse brain and spinal cord motoneurons. Eur J Neurosci 7:1080-1088.

Parmantier E, Braun C, Thomas JL, Peyron F, Martinez S, Zalc B (1997) PMP-22 expression in the central nervous system of the embryonic mouse defines potential transverse segments and longitudinal columns. J Comp Neurol 378:159-172.

Pesheva P, Horwitz AF, Schachner M (1987) Integrin, the cell surface receptor for fibronectin and laminin, expresses the L2/HNK-1 and L3 carbohydrate structures shared by adhesion molecules. Neurosci Lett 83:303-306.

Previtali SC, Feltri ML, Archelos JJ, Quattrini A, Wrabetz L, Hartung H (2001) Role of integrins in the peripheral nervous system. Prog Neurobiol 64:35-49.

Previtali SC, Dina G, Nodari A, Fasolini M, Wrabetz L, Mayer U, Feltri ML, Quattrini A (2003) Schwann cells synthesize alpha7betal integrin which is dispensable for peripheral nerve development and myelination. Mol Cell Neurosci 23:210-218.

Rabinovitz I, Mercurio AM (1997) The integrin alpha6beta4 functions in carcinoma cell migration on laminin-1 by mediating the formation and stabilization of actin-containing motility structures. J Cell Biol 139:1873-1884.

Re FC, Manenti G, Borrello MG, Colombo MP, Fisher JH, Pierotti MA, Della Porta G, Dragani TA (1992) Multiple molecular alterations in mouse lung tumors. Mol Carcinog 5:155-160.

Roa BB, Dyck PJ, Marks HG, Chance PF, Lupski JR (1993) Dejerine-Sottas syndrome associated with point mutation in the peripheral myelin protein 22 (PMP22) gene. Nat Genet 5:269-273.

Robaglia-Schlupp A, Pizant J, Norreel JC, Passage E, Saberan-Djoneidi D, Ansaldi JL, Vinay L, Figarella-Branger D, Levy N, Clarac F, Cau P, Pellissier JF, Fontes M (2002) PMP22 overexpression causes dysmyelination in mice. Brain 125:2213-2221.

Robertson AM, King RH, Muddle JR, Thomas PK (1997) Abnormal Schwann cell/axon interactions in the Trembler-J mouse. J Anat 190:423-432.

Robertson AM, Huxley C, King RH, Thomas PK (1999) Development of early postnatal peripheral nerve abnormalities in Trembler-J and PMP22 transgenic mice. J Anat 195:331-339.

Roux KJ, Amici SA, Notterpek L (2004) The temporospatial expression of peripheral myelin protein 22 at the developing blood-nerve and bloodbrain barriers. J Comp Neurol 474:578-588.

Roux KJ, Amici SA, Fletcher BS, Notterpek L (2005) Modulation of epithelial morphology, monolayer permeability, and cell migration by Gas3/ PMP22. Mol Biol Cell 16:1142-1151.

Ryan MC, Notterpek L, Tobler AR, Liu N, Shooter EM (2000) Role of the peripheral myelin protein $22 \mathrm{~N}$-linked glycan in oligomer stability. J Neurochem 75:1465-1474.

Sancho S, Young P, Suter U (2001) Regulation of Schwann cell proliferation and apoptosis in PMP22-deficient mice and mouse models of CharcotMarie-Tooth disease type 1A. Brain 124:2177-2187.

Schachner M, Martini R (1995) Glycans and the modulation of neuralrecognition molecule function. Trends Neurosci 18:183-191.

Scherer SS, Arroyo EJ (2002) Recent progress on the molecular organization of myelinated axons. J Peripher Nerv Syst 7:1-12.

Schmidt JT, Schachner M (1998) Role for cell adhesion and glycosyl (HNK-1 and oligomannoside) recognition in the sharpening of the regenerating retinotectal projection in goldfish. J Neurobiol 37:659-671.

Snipes GJ, Suter U, Shooter EM (1993) Human peripheral myelin protein-22 carries the L2/HNK-1 carbohydrate adhesion epitope. J Neurochem 61:1961-1964.

Sonnenberg A, Hogervorst F, Osterop A, Veltman FE (1988) Identification and characterization of a novel antigen complex on mouse mammary tumor cells using a monoclonal antibody against platelet glycoprotein Ic. J Biol Chem 263:14030-14038.

Suter U, Moskow JJ, Welcher AA, Snipes GJ, Kosaras B, Sidman RL, Buchberg AM, Shooter EM (1992) A leucine-to-proline mutation in the putative first transmembrane domain of the $22-\mathrm{kDa}$ peripheral myelin protein in the trembler-J mouse. Proc Natl Acad Sci USA 89:4382-4386. 
Taylor V, Welcher AA, Program AE, Suter U (1995) Epithelial membrane protein-1, peripheral myelin protein 22 , and lens membrane protein 20 define a novel gene family. J Biol Chem 270:28824-28833.

Tiwari-Woodruff SK, Buznikov AG, Vu TQ, Micevych PE, Chen K, Kornblum HI, Bronstein JM (2001) OSP/claudin-11 forms a complex with a novel member of the tetraspanin super family and betal integrin and regulates proliferation and migration of oligodendrocytes. J Cell Biol 153:295-305.

Tobler AR, Notterpek L, Naef R, Taylor V, Suter U, Shooter EM (1999) Transport of Trembler-J mutant peripheral myelin protein 22 is blocked in the intermediate compartment and affects the transport of the wildtype protein by direct interaction. J Neurosci 19:2027-2036.

Valenzuela DM, Murphy AJ, Frendewey D, Gale NW, Economides AN,
Auerbach W, Poueymirou WT, Adams NC, Rojas J, Yasenchak J, Chernomorsky R, Boucher M, Elsasser AL, Esau L, Zheng J, Griffiths JA, Wang X, Su H, Xue Y, Dominguez MG, et al. (2003) High-throughput engineering of the mouse genome coupled with high-resolution expression analysis. Nat Biotechnol 21:652-659.

van Dartel M, Hulsebos TJ (2004) Characterization of PMP22 expression in osteosarcoma. Cancer Genet Cytogenet 152:113-118.

Wadehra M, Iyer R, Goodglick L, Braun J (2002) The tetraspan protein epithelial membrane protein-2 interacts with betal integrins and regulates adhesion. J Biol Chem 277:41094-41100.

Wulf P, Bernhardt RR, Suter U (1999) Characterization of peripheral myelin protein 22 in zebrafish (zPMP22) suggests an early role in the development of the peripheral nervous system. J Neurosci Res 57:467-478. 